Revista Brasileira de Farmacognosia Brazilian Journal of Pharmacognosy 22(4): 906-920, Jul./Aug. 2012

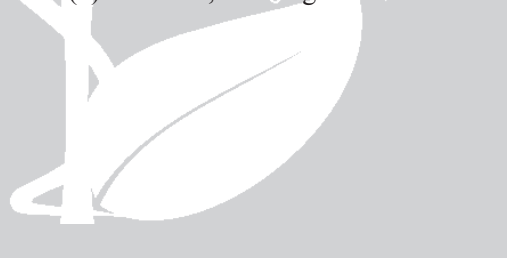

Review

Received 23 Nov 2011

Accepted 2 Jan 2012

Available online 15 May 2012

Keywords:

algicolous fungi

endophytic fungi

marine algae

marine natural products

ISSN 0102-695X

http://dx.doi.org/10.1590/S0102-

$695 X 2012005000060$

\section{Marine natural products: chemical and biological potential of seaweeds and their endophytic fungi}

\author{
Ana Lígia Leandrini de Oliveira, Rafael de Felício, Hosana \\ Maria Debonsi*
}

Departamento de Física e Química, Núcleo de Pesquisas de Produtos Naturais e Sintéticos, Faculdade de Ciências Farmacêuticas de Ribeirão Preto, Universidade de São Paulo, Brazil.

\begin{abstract}
Marine natural products have currently been recognized as the most promising source of bioactive substances for drug discovery research. In this review, extraordinary metabolites from marine algae species are illustrated, as well as approaches for their isolation and determination of their biological properties and pharmaceutical potential. Furthermore, marine endophytic microorganisms (from marine algae) are presented as a new subject for extensive investigation to find novel natural products, which make them a potentially rich and innovative source for new drug candidates.
\end{abstract}

\section{Introduction}

Over the last five decades, the study of marine natural products has been an intriguing and fruitful field for organic chemistry research. Marine organisms are prolific producers of structurally unique bioactive metabolites, including some with unusual mechanisms of action, besides diverse biosynthetic pathways (CostaLotufo et al., 2009). The ability of some sessile benthic species to synthesize bioactive molecules (including Porifera, Cnidarians, Bryozoans, Tunicates and marine algae) leads to competitive benefits in an ecosystem characterized by extreme resource limitations and converts these organisms into an important source for pharmaceutical prospecting (McClintock \& Baker, 2001).

The role of marine natural products in drug discovery began in the 1950s with the isolation of the nucleosides spongouridine (1) and spongothymidine (2) from the sponge Tectitethya crypta Laubenfels. These compounds inspired the synthesis of Cytarabine (Ara-C, 3) and Vidarabine (Ara-A, 4), anticancer and antiviral drugs now used for the treatment of acute myeloid leukemia and herpes virus infection, respectively (McClintock \& Baker, 2001). Currently, a promising list of marine-derived compounds is in clinical trials, besides two drugs approved by the U.S. Food and Drug Administration and the EU: Yondelis (5) and Prialt (6). Ziconotide (Prialt), a peptide originally isolated from the venom of Conus magus Linnaeus and an analogue of the $N$-type calcium channel blocker $\omega$-conotoxin MVIIA, is used clinically for the treatment of patients suffering from chronic pain. Trabectedin (Yondelis), a tetrahydroisoquinoline alkaloid isolated from the ascidia Ecteinascidia turbinata Herdman, was approved by the UE for the treatment of advanced soft tissue sarcoma (Butler, 2008; Costa-Lotufo et al., 2009; Hill, 2011).

In this context, the present work describes the main classes of compounds isolated from marine macroalgae, one of the first marine organisms to be explored for medical purposes. This report will focus on the most representative metabolites, considering the ones in clinical trials or new structures with promising pharmacological potential. In addition, we will present the intriguing metabolites isolated from endophytic fungi, fascinating microorganisms associated with marine algae, which have emerged as a new frontier for finding novel pharmaceutical candidates. Furthermore, this new productive source will be discussed on the basis of the unique structural characteristics responsible for their biological potential.

\section{Red algae}

Red algae (Rhodophyta, 98\% marine) are dynamic producers of halogenated compounds, ranging 
from peptides, polyketides, indoles, terpenes, acetogenins and phenols to volatile halogenated hydrocarbons (Cabrita et al., 2010; Fujii et al., 2011). Additionally, red algae synthesize large amounts of sulfated polysaccharides (cell wall constituents), as well as some shikimate and nucleic acid derivatives (Wijesekara et al., 2011; Güven et al., 2010). A wide variety of biological activities is associated with marine red algae metabolites, such as antibacterial, antifungal, antiviral, anti-inflammatory, antiproliferative, antifouling, antifeedant, cytotoxic, ichthyotoxic, and insecticidal properties.

Related to the marine red algae applications, aqueous extracts obtained from Digenea simplex (Wulfen) C. Agardh (Ceramiales, Rhodomelaceae) have been used as a vermifuge for centuries in the traditional medicine of East Asian countries, (Pei-Gen \& ShanLin, 1986). Further chemical studies were carried out, leading to the isolation of Kainic acid (KA), considered to be the main active compound in this extract. The anthelmintic amino acid KA (7) was later re-discovered as a neuroactive compound, acting in neuronal glutamate receptors (Hopkins et al., 2000; Sakai et al., 2005). The structure of KA is strictly related to other neuronal agonist amino acids, such as domoic acid, isolated from the red alga Chondria armata (Kützing) Okamura, as well as an anthelmintic compound (Sakai et al., 2005). Currently, kainoids have been used in neurobiological research as a standard reagent, playing an important role in studies of neurophysiological disorders such as Alzheimer, Parkinson and epilepsy (Higa \& Kuniyoshi, 2000; Smit, 2004).

Despite medicinal use, the early investigations in marine natural products focused on highly halogenated metabolites, such as the monoterpene halomon (8), isolated from the red algae Portieria hornemanni (Lyngbye) P. C. Silva (Clardy \& Walsh, 2004; Fuller et al., 1992). Halomon exhibited selective cytotoxicity to brain-, renal-, and colon-tumor cell lines in a National Cancer Institute screening and was selected for preclinical drug development. Halomon (8) has been considered to be one of the most promising metabolites of marine algae; however, its progress as an anticancer lead has disadvantages due to its limited accessibility and solubility (Andrianasolo et al., 2006; Sotokawa et al., 2000). Another interesting bioactive halogenated compound from marine red algae is the bicyclic diterpene laurenditerpenol (9). Isolated by means of bioassay-guided fractionation of the lipid extract from Laurencia intricata J. V. Lamouroux, laurenditerpenol is the first marine natural product that inhibited the hypoxia-inducible transcription factor (IC50 $0.4 \mu \mathrm{M}$ ); which has recently emerged as an key tumor-selective molecular target for anticancer drug development (Chittiboyina et al., 2007; Jung \& Im, 2008; Nagle \& Zhou, 2009). Moreover, Laurencia, belonging to the Rhodomelaceae family, is the most studied genus of phylum Rhodophyta and has been intensively investigated over the last fifty years. This vigorous research led to the discovery of diverse molecules with biological potential like the cytotoxic diterpene brasilenol (10) and the triterpene calicladol (11), and the antibacterial and cytotoxic C-15 acetogenines, such as laurencina (12), for example. Recently an overview of the taxonomy and major bioactive secondary metabolites from the Laurencia complex current in Brazil was published by Fujii et al. (2011).

In addition, with reference to red algae metabolites, there is a substantial amount of investigation related to the antiviral activity displayed by sulfated polysaccharides (Luescher-Mattli, 2003; Campo et al., 2009). Carrageenans (13) are the most common cell wall sulfo-polygalactans from Rhodophyta. The immunomodulatory effects of these polysaccharides were described as potent lectin-like $\mathrm{T}$ cell mitogens and polyclonal B cell activators (Luescher-Mattli, 2003). Carrageenans have been studied in the Gigartinaceae and Tichocarpacea families and also exhibited antioxidant, anticoagulant and antithrombic activities (Sokolova et al., 2011).

Although there are no drugs derived from red algae, it is clear that this phylum represents a potential source of bioactive molecules that should be explored more thoroughly. Furthermore, recently published data on marine red macroalgae describes new structures with biological potential. In Laurencia sp. a new brominated diterpene, 10-acetoxyangasiol (14), was discovered, which exhibited potent antibacterial activities against the clinical bacteria Staphylococcus aureus, Staphylococcus sp. and Vibrio cholerae (Vairappan et al., 2010). One more natural product, (5S)-5-acetoxycaespitol (15), isolated among seven new halogenated metabolites from the Brazilian red algae Laurencia catarinensis Cordeiro-Marino \& Fujii, demonstrated cytotoxic activity in different tumor cells lines (Lhullier et al., 2010). From the same genera, Laurencia, several compounds with fascinating structural diversity were recently published. This rich metabolite assortment is exemplified by the cytotoxic oxasqualenoid (16) (Cen-Pacheco et al., 2010), a new highly brominated aromatic compound (17) (Qin et al., 2010), a new tricyclic brominated diterpenoid (18) with in vitro and in vivo anti-inflammatory activity (Chatter et al., 2011) and a new halogenated terpenoid (19) and a new C15-acetogenin containing a cyclic ether (20) (Abdel-Mageed et al., 2010; Gutiérrez-Cepeda et al., 2011; Liu et al., 2010). Finally, a new bromophenol (21) with antioxidant activity was found in Rhodomela confervoides (Hudson) P. C. Silva (Li et al., 2011b), while lithothamnin A (22), a new and unique bastadin- 


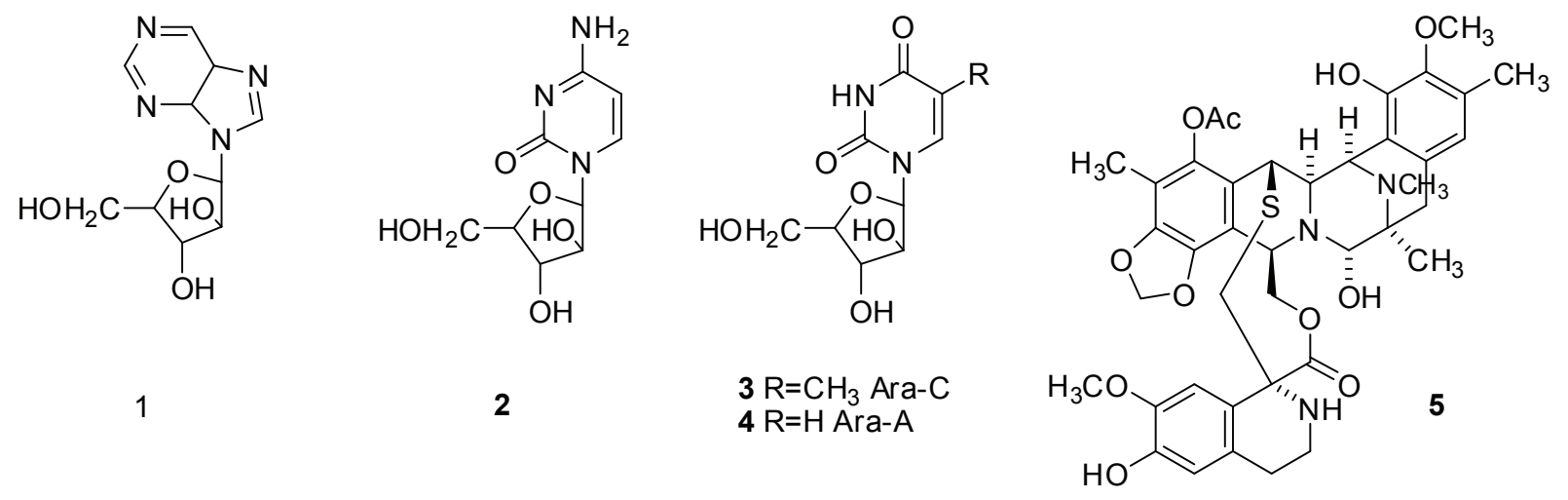

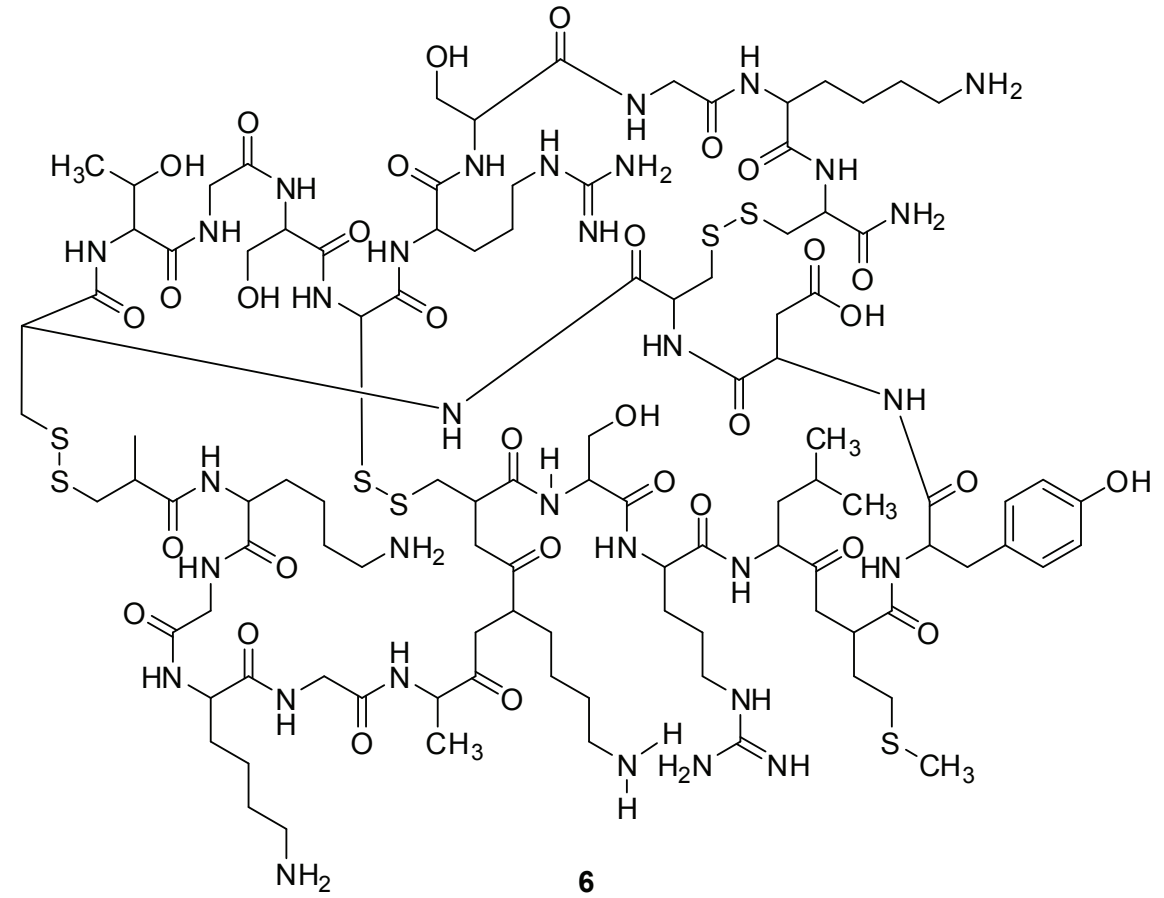<smiles>C=C(C)[C@@H]1CNC(C(=O)O)[C@H]1CC(=O)O</smiles>

7<smiles>C=C(Br)C(CBr)CCC(C)C(C)(C)Cl</smiles>

8<smiles>CC1=CC(O)C(CCCC2CC3(C)CCC2(C)O3)CC1</smiles>

9<smiles>CC1CCC2=C1C(O)C(C)(C)CC2C(C)C</smiles>

10<smiles>CC1C2CC(O)C(C3CCC(C4CCC(C(C)(C)O)O4)O3)CCC2OC1(C)C1CCC(O)C(C)(C)O1</smiles>

11<smiles>C=C/C=C\CC(C/C=C/C=C)[C@H]1C/C=C\C[C@@H](Br)[C@H](CC)O1</smiles>

12

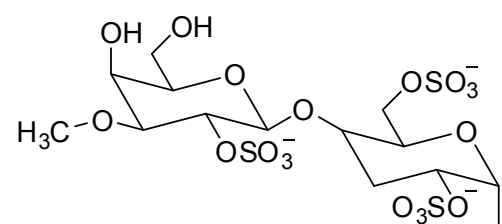

13 


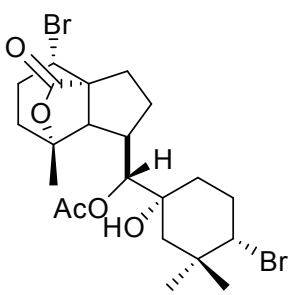

14<smiles>COC1CC2CC(C)(Cl)C(Br)CC(OC(C)(C)C(Br)CC2O)C1(C)C</smiles>

15<smiles>C[C@H](CC1O[C@@H](C2(C)CCC(Br)C(C)(C)O2)CC[C@@]1(C)O)C(=O)C(O)(CO)CC[C@H](O)[C@]1(C)CCC(C)(C(C)(C)O)O1</smiles>

16<smiles>COC1=CC(C(=O)c2cc(OC)c(OC)c(Br)c2Br)C(Br)C(Br)=C1OC</smiles>

17<smiles>C[C@H]1[C@@H](/C=C\C2CC[C@@](C)(O)[C@H](Br)C2)[C@@H](O)[C@@H]2CC[C@](C)(O)[C@H]12</smiles>

18<smiles>C#C/C=C\CC(O)[C@@H]1C[C@H]2O[C@H](C(Br)CC)C[C@H]2O1</smiles>

19<smiles>C#CCC/C=C/CC(Cl)[C@@H]1C[C@H](OC(C)=O)[C@@H](OC(C)=O)C=C[C@@H](CC)O1</smiles>

20<smiles>CS(=O)(=O)Cc1cc(O)c(O)c(Br)c1Br</smiles>

21<smiles></smiles>

22 like structure, was isolated from Lithothamnion fragilissimum Foslie (Wyk et al., 2011).

\section{Brown algae}

The phylum is almost exclusively marine and is known for producing major metabolites derived from isoprene (McClintock \& Baker, 2001). Besides the complex diterpenoids synthesized by brown algae, volatile compounds, fucoidans, phlorotannins and fucoxanthins exhibiting antioxidant, antibiotic, antifungal, antiviral, or anti-cancer activities have been reported (Folmer et al., 2010).

The main volatile compounds produced by marine brown algae are cyclic or acyclic short chain hydrocarbons (C8 or $\mathrm{C} 11)$, arising from enzymatic conversion of long chain fatty acids. These compounds are used as pheromones in sexual reproduction, while the decomposition products are employed in chemical defense (McClintock \& Baker, 2001; Rui \& Boland, 2010). Metabolites such as dictyotene (23) have been isolated from varied species and are related to the complex sexual reproduction process in this phylum.
However, some authors have associated the occurrence of these metabolites to restricted areas where there is a great variety of hydrocarbons due to oil pollution (Teixeira, 2009).

Fucoidans are sulfated polysaccharides (24) that have been reported to possess antiviral activity against infectious diseases, such as HIV, herpes simplex virus types (HSV-1 and HSV-2) and cytomegalovirus (Wijesekara et al., 2011). A fucoidan isolated from Cladosiphon okamuranus Tokida (Phaeophyceae) demonstrated strong inhibition against dengue virus type two infections. The results described by Hidari et al. (2008) indicate that fucoidan interacts directly with envelope glycoprotein on the virus. Consequently, this compound could be a candidate for development of a potential inhibitory agent against the dengue virus (Wijesekara et al., 2011).

Phlorotannins are tannin derivatives mainly isolated from brown algae, composed of several phloroglucinol units polymerized in different ways. Among all marine algae, the members of the Laminariaceae family are reported to be the richest source of phlorotannins (Thomas \& Kim, 2011; 
Wijesinghe \& Jeon, 2011). These structures could drive the drug discovery process, since they exhibit antioxidant, anti-inflammatory, antidiabetic, antitumor, antihypertensive and anti-allergic activities (Thomas \& Kim, 2011). Recently, the biological knowledge and the promising potential for cosmeceutical applications have been reviewed for phlorotannins, some alginates (25) and fucoxanthins (26) (Wijesinghe \& Jeon, 2011). Dieckol (27) has been reported as a promising target for application in antiaging and whitening formulations due to its exceptional protective activity against photooxidative stress, besides its tyrosinase inhibitory activity (Heo et al., 2009; Li et al., 2009).

Recently, the isolation of a new asymmetric bis-diterpene dictyotadimer A (28) from the genus Dictyota Lamouroux was reported (Viano et al., 2011), while at the same time antiviral diterpenes (29) were found in Dictyota menstrualis (Hoyt) Schetter, Höming \& Weber-Peukert (Cavalcanti et al., 2011). Ayyad et al. (2011) described the new diterpene amijiol acetate (30) from Dictyota dichotoma (Hudson) J. V.
Lamouroux, very interesting not only for its potent cytotoxicity against several different cell lines, but also for its antioxidant properties. New diterpenes featuring the 2,6-cyclo-xenicane skeleton (31) were isolated from Dilophus fasciola (Roth) J. V. Lamouroux and Dilophus spiralis (Montagne) G. Hamel (Ioannou et al., 2009). New brominated selinane (32) and cadinane (33) sesquiterpenes were reported from the genus Dictyopteris Lamouroux (Ji et al., 2009; Qiao et al., 2009; Wen et al., 2009). The cytotoxic activity of new bisprenylated quinols (34), accumulated in Sporochnus comosus C Agradh, were reported by Oveden et al. (2011). In addition, two dolastane diterpenes isolated from the Brazilian brown alga Canistrocarpus cervicornis (Kützing) De-Paula \& De Clerck were described as promising antiviral compounds (Vallim et al., 2010), besides phlorotannins from Ecklonia stolonifera Okamura and Eisenia bicyclis (Kiellman) Stchell, which were responsible for preventing diabetes complications (Moon et al., 2011).<smiles>CCCCC1C=CCC=CC1</smiles>

23

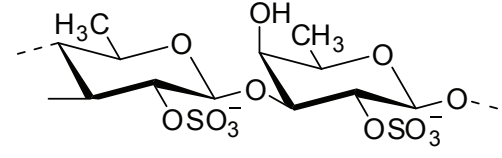

24

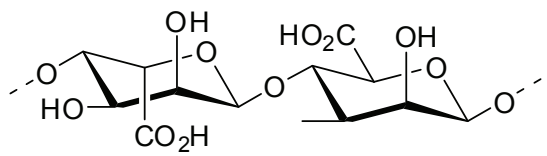

25<smiles>CCC=C(C)C</smiles><smiles>Oc1cc(O)cc(Oc2c(O)c(O)cc3c2Oc2cc(Oc4c(O)cc(Oc5c(O)c(O)cc6c5Oc5c(O)cc(O)cc5O6)cc4O)cc(O)c2O3)c1</smiles><smiles></smiles>

29

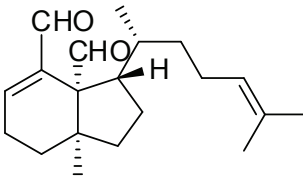

31

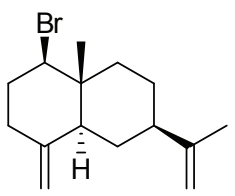

32 
<smiles></smiles>

33

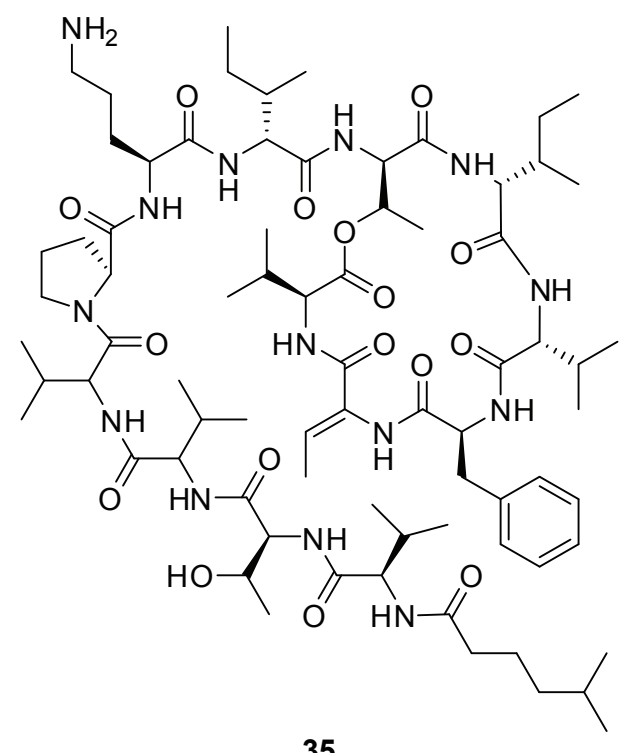

35<smiles>C=CC(C)(C)c1cc(O)c(/C=C\C(C)(C)O)cc1O</smiles>

34<smiles>CC(C)=CCC/C(C)=C/C1CC1(CO)C1CC=C(C=O)C1C=O</smiles>

36<smiles>Cc1c(O)c(O)c(Cc2ccc(O)c(Br)c2)c(C)c1Cc1cc(Br)c(O)c(O)c1Cc1ccc(O)c(Br)c1</smiles>

37<smiles>C=C(C)C(CC)CCC[C@H]1CCC2C3CC(O)C4=C[C@H](O)CC[C@]4(C)C3CC[C@]21C</smiles>

38

\section{Green algae}

The main representative substances of the phylum Chlorophyta are isoprenoid derivatives. Acetogenins, amino acid derivatives, carbohydrates and shikimate derivatives have also been isolated from these algae (McClintock \& Baker, 2001). Only a small percentage of this phylum belongs to the marine environment (13\%) and, consequently, they are the least representative macroalgae division in marine natural products chemistry.

The most remarkable in terms of bioactive metabolites isolated from marine green algae is the cyclic depsipeptide kahalide F (35). Kahalide F was initially obtained from the herbivorous sea slug Elysia rufescens; however, it is assumed that the genuine source of this compound is the chlorophyta Bryopsis sp., which is the main element of the sea slug's diet (Folmer et al., 2010). Kahalide F (35), developed by the Spanish biopharmaceutical company PharmaMar, is a novel antitumor drug candidate currently in phase II clinical trials and causes oncosis in cancer cells by lysosomal induction and cell membrane permeabilization (Folmer et al., 2010). Other metabolites isolated from green algae, like the diterpene halimedatrial (36) from Udotea flabellum (J.Ellis \& Solander) M. A. Howe and Halimeda sp. Lamouroux, besides the bromophenolic compound isorawsonol (37) from Avrainvillea rawsonii (Dickie) M. A. Howe, have demonstrated interesting anticancer potential (Folmer et al., 2010). Recently, a new sterol, 24- $R$-stigmasta-4,25-diene-3 $\beta, 6 \beta$-diol (38), among another known compounds, was isolated from Codium divaricatum Holmes, a traditional Chinese medicine used as an anticancer agent since the remote past (He et al., 2010). 
Endophytic marine microorganisms

Microbial natural products are a large and promising area for obtaining new and potent therapeutic agents (Demain, 2009; Lam, 2007). Combining the particularities of the marine environment and microbial versatility, marine microorganisms have been considered to be the most hopeful natural source for drug discovery (Glaser \& Mayer, 2009; Lam, 2007). Marine microorganisms have shown an excellent biosynthetic ability to generate bioactive metabolites (Jensen et al., 2005; Simmons et al., 2008).

Marine fungi comprise a small group of ecologically well-known filamentous ascomycetes, yeasts and their anamorphs (Pang \& Mitchell, 2005). The assumption regarding the strong symbiotic relationship between microorganisms and their invertebrate hosts has been increasingly solidified, since several studies indicate that the active substances isolated from sponges, sea squirts, and corals, among others, may actually have originated from their associated microorganisms (Glaser \& Mayer, 2009; Simmons et al., 2008). Moreover, of twenty substances derived from (or inspired by) marine organisms that are in final trial for approval as new cancer treatment drugs, sixteen are directly related to microbial biosynthesis and five are, in fact, isolated from microorganisms (Simmons et al., 2008).

Considering the fundamental role of microorganisms in the invertebrate's bioactive metabolite production, it is important to point out the relevance of the endophytism regarding macro- and microorganisms. Endophytic microorganisms consist of fungi and bacteria living at least part of their life cycle within the healthy tissue of their host (generally plants, algae or invertebrates), in a relationship that can diverge between latent phytopathogenesis and mutual symbiosis (Strobel et al., 2004; Tan \& Zou, 2001).

The complexity and importance of this ecological relationship are reflected in the chemical and biological potential of endophytes in natural products research. In general, the study of endophytic microorganisms represents a relatively new branch and, therefore, an unexplored field (Guo et al., 2009; Strobel et al., 2004). The association between algae and fungi has been well established; however, there are only a few studies with reference to metabolites isolated from fungi associated with marine algae inner tissues (Jones et al., 2008).

Table 1 summarizes unknown compounds isolated from fungi derived from marine algae inner tissues. To obtain endophytic fungi cultures, authors usually make use of superficial sterilization methods to avoid the isolation of epiphytic microorganism. Analyzing the data presented, we can infer that the search for new metabolites from marine red algae endophytic fungi is quite recent, the first report being from the beginning of the last decade. An evident growth in interest in this field is justified by 33 papers dealing with chemical investigations of endophytic fungi from marine algae, more than $50 \%$ of which appeared in the literature after 2008.

Related to the endophytic fungal source, it is clear that the fungi were isolated from the most representative species belonging to different macroalgae phylum. These algal species had already been studied, such as the green ones from the genera Codium Stackhouse and Ulva L. (including Enteromorpha Link in Nees), the brown algae from the genera Sargassum C. Agardh and Fucus, and Laurencia as the red algae example. In addition, there is no problem with the marine algae, since its role is just to serve a host for the endophytic microorganisms, as noted in Table 1. Moreover, these marine seaweed species are responsible for the great chemical structure diversity, besides the expressive biological potential.

The metabolites derived from endophytes collected from marine green algae presented, in general, bicyclical structures with some oxygenations or even aromatic moieties, demonstrating cytotoxicity, antiprotozoa and antimicrobial activities (Elsebai et al., 2010; Zhu et al., 2009; El-Beih et al., 2007; Osterhage et al., 2000), besides fat-accumulation inhibitory activity (Almeida et al., 2010), modulation of carcinogen metabolizing enzymes and protection from DNA damage (Gamal-Elden et al., 2009).

Related to substances obtained from endophytes associated with brown algae, we can highlight a greater structural and bioactivity assortment: naphto- and pyrone derivatives presenting antifungal and antioxidant activity (Zhang et al., 2010; Zhang et al., 2007a, b), macrolides showing antibacterial potential (Holler et al., 2000; Yang et al., 2006), isobenzofuranone derivative and bicyclic lactones (Abdel-Lattef et al., 2003; Osterhage et al., 2002a), antioxidant benzodiazepine derivatives (Cui et al., 2009) and cytotoxic ergosterolide derivates with an unusual pentalactone B-ring (Cui et al., 2010).

Considering red algae as the source of endophytes, the metabolites also presented some interesting chemical structure variations and biological potential. Some examples are the new oxylipin and steroidal acetylcholinesterase inhibitors (Qiao et al., 2011); curvularin-type macrolides presenting antibacterial, antifungal and algicide properties (Dai et al., 2011), several classes of terpenes like the antimicrobial indoloterpenes (Qiao et al., 2010), sesquiterpenoids with antiplasmodial activity (Osterhage et al., 2002b), tetracyclic diterpenes (Gao et al., 2011a) and one antimicrobial monoterpene (Gao et al., 2011b). Moreover, other interesting properties are exemplified by polyoxygenated compounds with antifungal potential, 
cytotoxic steroids with tetrahydroxy and C-16-acetoxy groups (Gao et al., 2011c), antimicrobial and cytotoxic polyketides (Gao et al., 2011b), aromatic pentaketides of the dihydroisocoumarins class (Pontius et al., 2008a) and cytotoxic benzaldehyde derivatives (Wang et al., 2006).

Finally, we point out some characteristics of metabolites from unidentified marine algae endophytes: antioxidant hydroquinone derivates (Abdel-Lattef et al., 2002), prenylated polyketide benzophenone derivatives (Kralj et al., 2006), monomeric xanthones showing cancer chemopreventive action by inhibition of cytochrome P450 and other correlated enzymes (Krick et al., 2007). Exploring carbonylated structures, some motivating compounds include the dihydroisocoumarins derived from aromatic pentaketides (Pontius et al., 2008a), dimeric chromanones and some other polyketides containing two uniquely modified xanthone derived units, besides enzyme inhibitor properties (Pontius et al., 2008a,c) and a rubralactone derivative showing enzymatic inhibition of DNA polymerase (Naganuma et al., 2008).

Table 1. Unknown substances isolated from marine algae endophytic fungi.

\begin{tabular}{|c|c|c|c|c|}
\hline & Algae(host) & Fungi(endophyte) & $\begin{array}{l}\text { Structures* } \\
\text { number }\end{array}$ & Reference \\
\hline \multirow{7}{*}{ 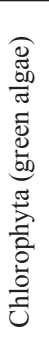 } & Blidingia minima (Nägeli ex Kützing) Kylin & Penicillium sp. & 39 & Zhu et al., 2009 \\
\hline & Codium fragile (Suringar) Hariot & Valsa ceratosperma (Tode ex Fries) Maire & 40 & El-Beih et al., 2007 \\
\hline & Enteromorpha sp. & $\begin{array}{l}\text { Cadophora malorum (Kidd \& Beaumont) W. } \\
\text { Gams }\end{array}$ & $41-44$ & Almeida et al., 2010 \\
\hline & Enteromorpha sp. & Coniothyrium cereale E. Müll & $45-51$ & Elsebai et al., 2010 \\
\hline & Ulva sp. & Ascochyta salicorniae Magnus apud Jaap & $52-54$ & Osterhage et al., 2000 \\
\hline & Ulva sp. & Penicillium sp. & 55 & Gamal-Elden et al., 2009 \\
\hline & Valonia utricularis (Roth) C.Agardh & Chaetomium sp. & 56 & Abdel-Lateff, 2008 \\
\hline \multirow{6}{*}{ 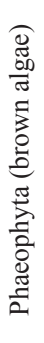 } & $\begin{array}{l}\text { Colpomenia sinuosa (Mertens ex Roth) } \\
\text { Derbès \& Solier }\end{array}$ & Aspergillus niger Van Tieghem & $57-62$ & $\begin{array}{l}\text { Zhang et al., 2007a,b; } \\
\text { Zhang et al., } 2010\end{array}$ \\
\hline & Cytoseira sp. & Varicosporina ramulosa Meyers et Kohlm & 63,64 & Holler et al., 2000 \\
\hline & Fucus spiralis L. & Phoma tropica R. Schneid. \& Boerema & 65 & Osterhage et al., 2002a \\
\hline & Fucus vesiculosus L. & Epicoccum sp. & 66 & Abdel-Lateff et al., 2003 \\
\hline & Sargassum sp. & Not identified & 67,68 & Yang et al., 2006 \\
\hline & Sargassum kjellmanianum Yendo & Aspergillus ochraceus Wilhelm & $69-72$ & $\begin{array}{l}\text { Cui et al., } 2009 \text { Cui et } \\
\text { al., } 2010\end{array}$ \\
\hline \multirow{9}{*}{ 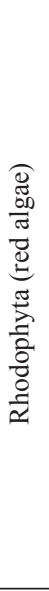 } & Corallina officinalis L. & $\begin{array}{l}\text { Aspergillus flavus Johann Heinrich. Friedrich } \\
\text { Link }\end{array}$ & 73,74 & Qiao et al., 2011 \\
\hline & Gracilaria folifera (Forsskål) Borgesen & Curvularia sp. & 75,76 & Dai et al., 2011 \\
\hline & Heterosiphonia japonica Yendo & Aspergillus oryzae (Ahlburg) E. Cohn & $77-79$ & Qiao et al., 2010 \\
\hline & $\begin{array}{l}\text { Kappaphycus alvarezii (Doty) Doty ex } \\
\text { P.C.Silva }\end{array}$ & Mycelium sterillium (KT 29) & 80 & Tarman et al., 2011 \\
\hline & Liagora viscida (Forsskål) C.Agardh & $\begin{array}{l}\text { Drechslera dematioidea (Bubak \& Wroblewski) } \\
\text { Subram, \& Jain }\end{array}$ & $81-90$ & Osterhage et al., 2002b \\
\hline & Laurencia sp. & Penicillium chrysogenum Thom & 91-98 & Gao et al., 2011a,b,c \\
\hline & Laurencia similis Nam \& Saito & $\begin{array}{l}\text { Exophialia oligosperma Calendron ex de Hoog } \\
\text { \& Tintelnot }\end{array}$ & $99 * *$ & Li et al., 2011a \\
\hline & Plocamium sp. & Acremonium sp. & 100 & Pontius et al., 2008a \\
\hline & $\begin{array}{l}\text { Polysiphonia urceolata (Lightfoot ex } \\
\text { Dillwyn) Greville }\end{array}$ & Chaetomium globosum Kunze & 101 & Wang et al., 2006 \\
\hline \multirow{5}{*}{ 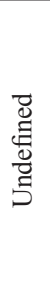 } & & Acremonium sp. & 102,103 & Abdel-Lateff et al., 2002 \\
\hline & & $\begin{array}{l}\text { Emericella nidulans var. acristata (Fennell \& } \\
\text { Raper) Subram }\end{array}$ & 104,105 & Kralj et al., 2006 \\
\hline & & Monodictys putredinis (Wallr.) Hughes & $106-111$ & $\begin{array}{l}\text { Krick et al., 2007; } \\
\text { Pontius et al., } 2008 \text { b }\end{array}$ \\
\hline & & Nodulisporium sp. & 112,113 & Pontius et al., 2008a,c \\
\hline & & Not identified & 114 & Naganuma et al., 2008 \\
\hline
\end{tabular}


<smiles>CC1=C2[C@H](C)C(C)OOC23OC(C)C(=O)CC3(O)O[C@H](C)[C@@H]1C</smiles>

39<smiles>C[C@H]1C[C@H](O)CC(O)=C2C(=O)C[C@@H](C)[C@H](C)[C@H]21</smiles>

40<smiles>[R]CC1=C[C@@H]2C([R4])C=CC(C(=O)O)C2C(C([R3])(C)C[R])CC1</smiles>

$41 \mathrm{R}_{1}=\mathrm{OH} ; \mathrm{R}_{2}=\mathrm{R}_{3}=\mathrm{R}_{4}=\mathrm{H}$ $42 \mathrm{R}_{2}=\mathrm{OH} ; \mathrm{R}_{1}=\mathrm{R}_{3}=\mathrm{R}_{4}=\mathrm{H}$ $43 \mathrm{R}_{3}=\mathrm{OH} ; \mathrm{R}_{1}=\mathrm{R}_{2}=\mathrm{R}_{4}=\mathrm{H}$ $44 \mathrm{R}_{4}=\mathrm{OH} ; \mathrm{R}_{1}=\mathrm{R}_{2}=\mathrm{R}_{3}=\mathrm{H}$

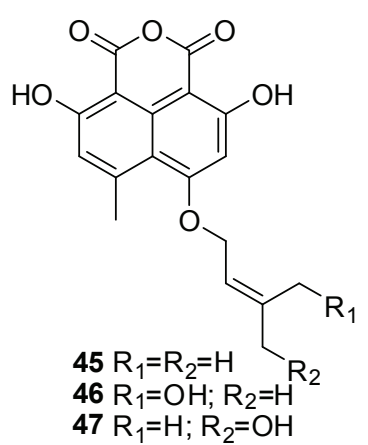<smiles>CC(C)=CCOc1cc(O)c2c3c(c(O)cc(C)c13)C(=O)OC2=O</smiles>

49<smiles>[X]C(=O)c1c(O)cc(OCC=C(C)C)c2c(C)cc(O)c([X])c12</smiles>

$50 \mathrm{X}=\mathrm{CO}$ $51 \mathrm{X}=\mathrm{O}$

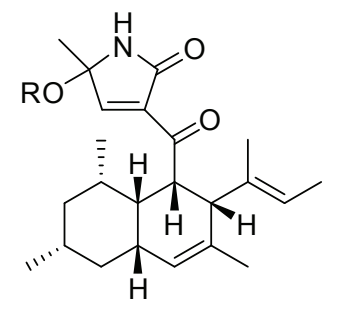

$52 \mathrm{R}=\mathrm{CH}_{2} \mathrm{CH}_{2} \mathrm{CH}_{2} \mathrm{CH}_{3}$ $53 \mathrm{R}=\mathrm{CH}_{3}$<smiles>CCC(C)C(=O)C(C)c1cc(O)c(C)c(=O)o1</smiles>

54<smiles>COc1cc(OC)c2c(O)c3c(=O)cc(CO)oc3cc2c1</smiles>

58<smiles>COc1cc(OC)c2c(O)c3c(c(-c4c(OC)cc5cc(O)c6c(c5c4OC)OC(C)(O)CC6=O)c2c1)OC(C)(O)CC3=O</smiles>

59<smiles>COc1cc(OC)c2c(O)c3c(c(-c4c(OC)cc5cc6occc(=O)c6c(O)c5c4OC)c2c1)OC(C)(C)CC3=O</smiles>

60<smiles>[X]C(Cc1ccccc1)c1cc(OC)cc(=O)o1</smiles>

$61 \mathrm{X}=\mathrm{HCOCH}_{3}$ $62 \mathrm{x}=\mathrm{OH}$<smiles>[R]C([R])C([R])(CCC(=O)OC(C)CC=CC(=O)OCC)C([R])[R]</smiles>

$63 \mathrm{R}_{1}=\mathrm{R}_{4}=\mathrm{H} ; \mathrm{R}_{2}=\mathrm{R}_{3}=\mathrm{OH}$ $64 \mathrm{R}_{1}=\mathrm{R}_{4}=\mathrm{OH} ; \mathrm{R}_{2}=\mathrm{R}_{3}=\mathrm{H}$<smiles>C[C@@H]1C[C@H]2C(=C(O)CC[C@@H]2O)C(=O)O1</smiles>

65<smiles>Cc1c(O)c(O)c(O)c2c1C(=O)OC2</smiles>

66<smiles>CC1CCC(=O)CCCCc2cc(O)cc(O)c2C1=O</smiles>

67<smiles>COc1cc(O)cc(/C=C/CCCCC(C)O)c1C(=O)O</smiles>

68<smiles>C[C@H]1NC(=O)c2cc(O)c(O)cc2-n2c1nc1ccccc1c2=O</smiles> 
<smiles>C=C(CCCCC(C)C1CCC2C3=C(CC[C@]21C)[C@@]1(C)CC[C@@H](O)C[C@H]1C(=O)O3)C(C)C</smiles>

70<smiles>CCCCC/C=C\C(O)C(O)/C=C/CCCCCCC(=O)O</smiles>

73

75

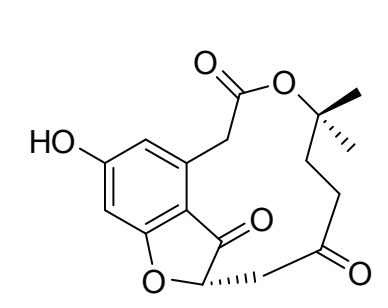<smiles>[R]C1C[C@]2(C)[C@@H](CC[C@@H]2C(C)CCCCC(=C)C(C)C)C2=C1[C@]1(C)CC[C@@H](O)C[C@H]1CC2=O</smiles>

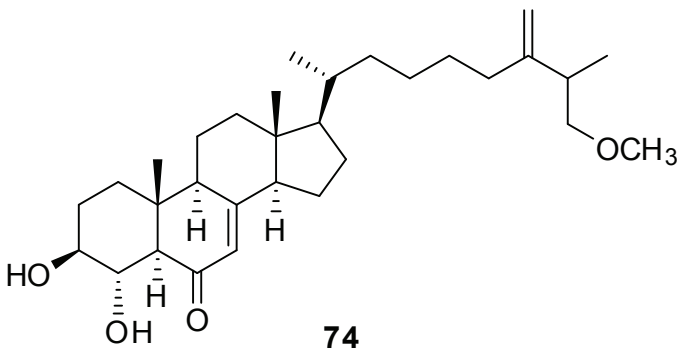<smiles>COC(=O)Cc1cc(O)cc(O)c1C(=O)C[C@@H]1CCC[C@H](C)O1</smiles>

76

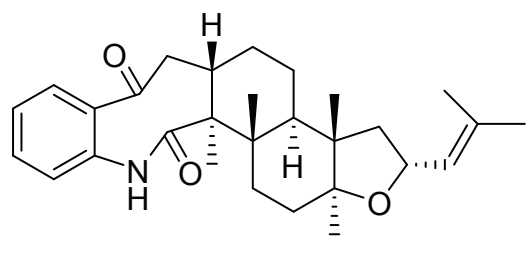

77

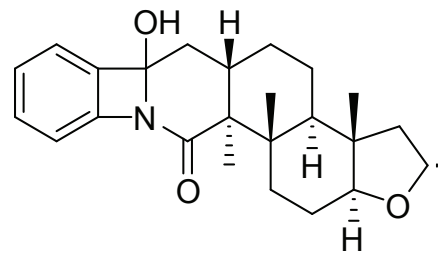

78

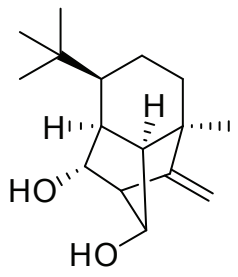

81

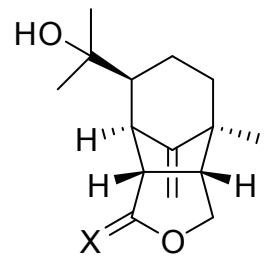

$85 \mathrm{X}=\mathrm{O}$

$86 \mathrm{X}=\alpha-\mathrm{H}, \beta-\mathrm{OCH}_{3}$<smiles>CC=C(C)C</smiles>

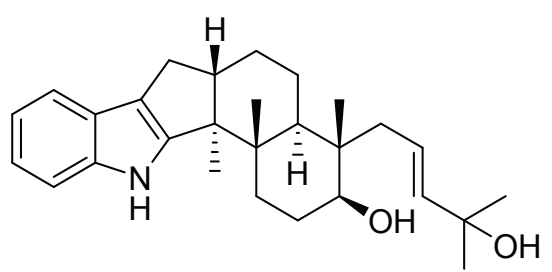

79<smiles>COc1cccc2ccc(C(=O)O)c(O)c12</smiles>

80<smiles>CC(C)(O)[C@H]1CC[C@@]2(C)C(CO)=C(CO)[C@H]1[C@H]2CO</smiles>

84

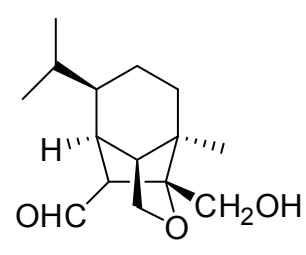

89 


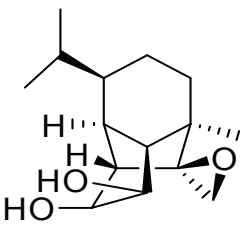

90

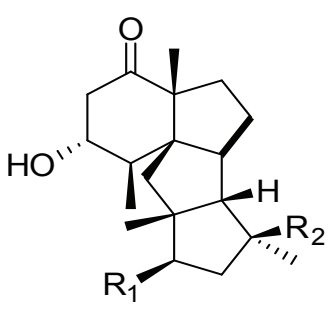

$91 \mathrm{R}_{1}=\mathrm{OH} ; \mathrm{R}_{2}=\mathrm{OCH}_{3}$

$92 \mathrm{R}_{1}=\mathrm{H} ; \mathrm{R}_{2}=\mathrm{CH}_{2} \mathrm{OH}$<smiles>CC(=O)OC/C(C)=C/CC[C@](C)(O)CC(=O)O</smiles>

96<smiles>c1ccc(Oc2ccc3ccccc3c2)cc1</smiles>

99<smiles>[R]Oc1ccc(O)c2c1C(C(=C)C)C2</smiles>

$102 \mathrm{R}=\mathrm{H}$

$103 \beta$-D-glucopyranose<smiles>[R]c1cc(O)c2c(c1)O[C@]1(C)[C@@H](O)[C@H]([R2])C[C@H](O)[C@@]21C</smiles>

$106 \mathrm{R}_{1}=\mathrm{CH}_{3} ; \mathrm{R}_{2}=\mathrm{OH}$

$107 \mathrm{R}_{1}=\mathrm{H} ; \mathrm{R}_{2}=\mathrm{CH}_{3}$

$108 \mathrm{R}_{1}=\mathrm{OCH}_{3} ; \mathrm{R}_{2}=\mathrm{CH}_{3}$<smiles>Cc1cc(O)c(O)c2c1C[C@@H](C)OC2=O</smiles><smiles>[R2][C@@H](C)CCC([R2])(C)CC(C)CCCC[C@@H]1C[C@@H]([R3])CC(=O)O1</smiles>

$93 \mathrm{R}_{1}=\mathrm{R}_{2}=\mathrm{H} ; \mathrm{R}_{3}=\mathrm{OH}$

$94 \mathrm{R}_{1}=\mathrm{H} ; \mathrm{R}_{2}=\mathrm{R}_{3}=\mathrm{OH}$

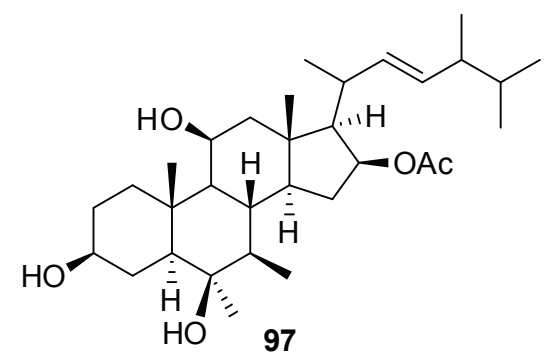<smiles>CCCc1c(Cl)c(OC)cc(OC)c1C(=O)O</smiles>

100<smiles>CC(C)=CCOc1ccc(O)c2c1C(O)Oc1c(CC=C(C)C)cc(CC=C(C)C)c(O)c1C2=O</smiles>

104<smiles>Cc1cc(O)c2c(c1-c1ccc3c(c1O)C(=O)C[C@](C)([C@]1(C)OC(=O)C[C@H]1C)O3)O[C@](C)(C1OC(=O)C[C@H]1O)C(=O)C2</smiles> 
<smiles>COC(=O)[C@@]1(C2CCC(=O)O2)CC(=O)c2c(cc(C)c(-c3c(C)cc(O)c4c3O[C@@](C(=O)OC)(C3CCC(=O)O3)CC4=O)c2O)O1</smiles><smiles>COc1cc(O)c2c(=O)oc3c(c2c1)C(C)CC3=O</smiles>

114

\section{Conclusion}

Marine organisms have been the focus of interesting discoveries, which have led to important drugs actually available from the pharmaceutical industry, such as Ara-A, Ara-C, Yondelis and Prialt. Since the early studies concerning the marine environment, seaweeds have emerged as a vast source of unique structures and bioactive metabolites. Currently, an innovative approach that has been taken is the isolation of endophytic microorganisms from macroalgae, exploring an interesting ecological relationship. This new research frontier, which represents a new natural products source to be explored, implies that, in the future, the intriguing chemical structures already isolated from these microorganisms may provide highquality drug candidates to improve human health.

\section{References}

Abdel-Lateff A, König GM, Fisch KM, Höller U, Jones PG, Wright AD 2002. New antioxidant hydroquinone derivatives from the algicolous marine fungus Acremonium sp. J Nat Prod 65: 1605-1611.

Abdel-Lateff A, Fisch KM, Wright AD, König GM 2003. A new antioxidant isobenzofuranone derivative from the algicolous marine fungus Epicoccum sp. Planta Med 69: 831-834.

Abdel-Lateff A 2008. Chaetominedione, a new tyrosine kinase inhibitor isolated from the algicolous marine fungus Chaetomium sp. Tetrahedron Lett 49: 6398-6400.

Abdel-Mageed WM, Ebel R, Valeriote FA, Jaspars MJ 2010. Laurefurenynes A-F, new cyclic ether acetogenins from a marine red alga, Laurencia sp. Tetrahedron 66: 2855-2862.

Andrianasolo EH, France D, Cornell-Kennon S, Gerwick WH 2006. DNA methyl transferase inhibiting halogenated monoterpenes from the Madagascar red marine alga Portieria hornemannii. J Nat Prod 69: 576-579.

Almeida C, Eguereva E, Kehraus S, Siering C, König GM 2010. Hidroxylated sclerosporin derivatives from the marine-derived fungus Cadophora malorum. J Nat Prod 73: 476-478.
Ayyad SN, Makki MS, Al-kayal NS, Basaif SA, El-Foty KO, Asiri AM, Alarif WM, Badria FA 2011. Cytotoxic and protective DNA damage of three new diterpenoids from the brown alga Dictyota dichotoma. Eur J Med Chem 46: 165-172.

Butler MS 2008. Natural products to drugs: natural productderived compounds in clinical trials. Nat Prod Rep 25: 475-561.

Cabrita MT, Vale C, Rauter, AP 2010. Halogenated compounds from marine algae. Mar Drugs 8: 2301-2317.

Campo VL, Kawano DF, da Silva DB, Carvalho I 2009. Carrageenans: Biological properties, chemical modifications and structural analysis-A review. Carbohyd Polym 77: 167-180.

Cavalcanti DN, Oliveira MR, De-Paula JC, Barbosa LS, Fogel T, Pinto MA, Paixão ICNP, Teixeira VL 2011. Variability of a diterpene with potential antiHIV activity isolated from the Brazilian brown alga Dictyota menstrualis. J Appl Phycol 23: 873-876.

Cen-Pacheco F, Villa-Pulgarin JA, Mollinedo F, Norte M, Daranas AH, Fernández JJ 2011 Cytotoxic oxasqualenoids from the red alga Laurencia viridis. Eur J Med Chem 46: 3302-3308.

Chatter R, Othman RB, Rabhi S, Kladi M, Tarhouni S, Vagias C, Roussis V, Guizani-Tabbane L, Kharrat R 2011. In vivo and in vitro anti-inflammatory activity of neorogioltriol, a new diterpene extracted from the red algae Laurencia glandulifera. Mar Drugs 9: 12931306.

Chittiboyina AG, Gundluru MK, Carvalho P 2007 Total synthesis and absolute configuration of laurenditerpenol: a HIF-1 activation inhibitor. $J$ Med Chem 50: 6299-6302.

Clardy J, Walsh C 2004. Lessons from natural molecules. Nature 432: 829-837.

Costa-Lotufo LV, Wilke DV, Jimenez PC 2009. Organismos marinhos como fonte de novos fármacos: histórico \& perspectivas. Quim Nova 32: 703-716.

Cui CM, Li XM, Li HF, Gao SS, Wang BG 2009. Benzodiazepine alkaloids from marine-derived endophytic fungus Aspergillus ochraceus. Helv Chim Acta 92: 1366-1370.

Cui CM, Li XM, Meng L, Li CS, Huang CG, Wang BG 
2010. 7-Nor-ergosterolide, a pentalactone- containing norsteroid and related steroids from the marinederived endophytic Aspergillus ochraceus EN-31. J Nat Prod 73: 1780-1784.

Dai J, Krohn K, Flörke U, Pescitelli G, Kerti G, Papp T, Kövér KE, Bényei AC, Draeger S, Schulz B, Kurtán T 2011. Curvularin-type metabolites from the fungus Curvularia sp. isolated from a marine alga. Eur J Org Chem 36: 6928-6937.

Demain AL 2009. Antibiotics: natural products essential to human health. Med Res Rev 29: 821-842.

El-Beih AA, Kato H, Ohta T, Tsukamoto S 2007. (3R, 4aR,5S,6R)-6-Hydroxy-5-methylramulosin: a new ramulosin derivative from a marine-derived sterile mycelium. Chem Pharm Bull 55: 953-954.

Elsebai MF, Kehraus S, Lindequist U, Sasse F, Shaaban S, Gütschow M, Josten M, Sahl HG, König GM 2010. Antimicrobial phenalenone derivatives from the marine-derived fungus Coniothyrium cereal. Org Biomol Chem 9: 802-808.

Folmer F, Jaspars M, Dicato M, Diederich M 2010. Photosynthetic marine organisms as a source of anticancer compounds. Phytochem Rev 9: 557-579.

Fujii MT, Cassano M, Stein EM, Carvalho, LR 2011. Overview of the taxonomy and of the major secondary metabolites and their biological activities related to human health of the Laurencia complex (Ceramiales, Rhodophyta) from Brazil. Rev Bras Farmacogn 21: 268-282.

Fuller RW, Cardellina JH, Kato Y, Brinen LS, Clardy J, Snader KM, Boyd MR 1992. A pentahalogenated monoterpene from the red alga Portieria hornemannii produces a novel cytotoxicity profile against a diverse panel of human tumor cell lines. J Med Chem 35: 3007-3011.

Gamal-Eldeen AM, Abdel-LateffA, Okino T 2009. Modulation of carcinogen metabolizing enzymes by chromanone A; a new chromone derivative from algicolous marine fungus Penicillium sp. Environ Toxicol Phar 28: 317 322.

Gao SS, Li XM, Zhang Y, Li CS, Wang BG 2011a. Conidiogenones $\mathrm{H}$ and $\mathrm{I}$, two new diterpenes of cyclopiane class from a marine-derived endophytic fungus Penicillium chrysogenum QEN-24S. Chem Biodivers 8: 1748-1753.

Gao SS, Li XM, Du FY, Li CS, Proksch P, Wang BG 2011 b. Secondary metabolites from a marine-derived endophytic fungus Penicillium chrysogenum QEN24S. Mar Drugs 9: 59-70.

Gao SS, Li XM, Li CS, Proksch P, Wang BG 2011c. Penicisteroids $\mathrm{A}$ and $\mathrm{B}$, antifungal and cytotoxic polyoxygenated steroids from the marine alga-derived endophytic fungus Penicillium chrysogenum QEN24S. Bioorg Med Chem Lett 21: 2894-2897.

Glaser KB, Mayer AMS 2009. A renaissance in marine pharmacology: from preclinical curiosity to clinical reality. Biochem Pharmacol 78: 440-448.

Guo B, Wang Y, Sun X, Tang K 2008. Bioactive natural products from endophytes: a review. Appl Biochem Micro+ 44: 136-142.

Gutiérrez-Cepeda A, Fernández JJ, Gil LV, López-Rodríguez M, Norte M, Souto ML 2011. Nonterpenoid C15 acetogenins from Laurencia marilzae. J Nat Prod 74: 441-448.

Güven KC, Percot A, Sezik E 2010. Alkaloids in marine algae. Mar Drugs 8: 269-284.

He Z, Zhang A, Ding L, Lei X, Sun J, Zhang L 2011. Chemical composition of the green alga Codium Divaricatum Holmes. Fitoterapia 81: 1125-1128.

Heo SJ, Ko SC, Cha SH, Kang DH, Park HS, Choi YU, Kim D Jung WK, Jeon YJ 2009. Effect of phlorotannins isolated from E. cava on melanogenesis and their protective effect against photo-oxidative stress induced by UV-B radiation. Toxicol In Vitro 23: 11231130.

Hidari KIPJ, Takahashi N, Arihara M, Nagaoka M, Morita K, Suzuki T 2008. Structure and anti-dengue virus activity of sulfated polysaccharide from a marine alga. Biochem Bioph Res Co 376: 91-95.

Higa T, Kuniyoshi M 2000. Toxins associated with medicinal and edible seaweeds. J Toxicol Toxin-Rev 19: 119137.

Hill RA 2011. Marine natural products. Annu Rep Prog Chem B 107: 138-156.

Höller U, König GM, Wright AD 1999. A new tyrosine inhibitor from a marine isolate of Ulocladium botrytis and new metabolites from the marine fungi Asteromyces cruciatus and Varicosporina ramulosa. Eur J Org Chem 1999: 2949-2955.

Hopkins KJ, Wang G-J, Schmued LC 2000. Temporal progression of kainic acid induced neuronal and myelin degeneration in the rat forebrain. Brain Res 864: 69-80.

Ioannou E, Zervou M, Ismail A, Ktari L, Vagias C, Roussis V 2009. 2,6-Cyclo-xenicanes from the brown algae Dilophus fasciola and Dilophus spiralis. Tetrahedron 65: 10565-10572.

Jensen PR, Mincer TJ, Williamsn PG, Fenical W 2005. Marine actinomycete diversity and natural product discovery. Antonie van Leeuwenhoek 87: 43-48.

Ji N-Y, Wen W, Li X-M, Xue Q-Z, Xiao H-L, Wang B-G 2009. Brominated Selinane Sesquiterpenes from the Marine Brown Alga Dictyopteris divaricata. Mar Drugs 7: 355-360.

Jones EBG, Stanley SJ, Pinruan U 2008. Marine endophyte sources of new chemical natural products: a review. Bot Mar 51: 163-170.

Jung ME, Im GYJ 2008. Convergent total synthesis of the racemic HIF-1 inhibitor laurenditerpenol. Tetrahedron Lett 49: 4962-4964. 
Kralj A, Kehrarus S, Krick A, Eguereva E, Kelter G, Maurer M, Wortmann A, Fiebig HH, König GM 2006. Arugosins $\mathrm{G}$ and $\mathrm{H}$ : prenylated polyketides from the marine-derived fungus Emericella nidulans var. acristata. J Nat Prod 69: 995-1000.

Krick A, Kehraus S, Gerhäuser C, Klimo K, Nieger M, Maier A, Fiebig HH, Atodiresei I, Raabe G, Fleischhauer J, König GM 2007. Potential cancer chemopreventive in vitro activities of monomeric xanthone derivatives from the marine algicolous fungus Monodictys putredinis. J Nat Prod 70: 353-360.

Lam KS 2007. New aspects of natural products in drug discovery. Trends Microbiol 15: 279-289.

Lhullier C, Falkenberg M, Ioannou E, Quesada E, Papazafiri P, Horta PA, Schenkel EP, Vagias C, Roussis V 2010. Cytotoxic halogenated metabolites from the Brazilian red alga Laurencia catarinensis. J Nat Prod 73: 27-32.

Li F, Li K, Li X, Wang B 2011a. Chemical constituents of marine algal-derived endophytic fungus Exophiala oligosperma EN-21. Chin J Oceanol Limn 29: 63-67.

Li K, Li X-M, Gloer JB, Wang B-G 2011b. Isolation, characterization, and antioxidant activity of bromophenols of the marine red alga Rhodomela confervoides. J Agric Food Chem 59: 9916-9921.

Li Y, Quian ZJ, Ryu B, Lee SH, Kim MM, Kim SK 2009. Chemical components and its antioxidant properties in vitro: an edible marine brown alga, E. cava. Bioorg Med Chem 17: 1963-1973.

Liu X, Li XM, Li CS, Ji NY, Wang, BG 2010. Laurenidificin, a new brominated $\mathrm{C} 15$-acetogenin from the marine red alga Laurencia nidifica. Chin Chem Lett 21: 1213 1215.

Luescher-Mattli M 2003. Algae, a possible source for new drugs in the treatment of HIV and other viral diseases. Curr Med Chem 2: 219-225.

McClintock JB, Baker BJ 2001. Marine Chemical Ecology. New York: CRC Press.

Moon HE, Islam MN, Ahn BR, Chowdhury SS, Sohn HS, Jung HA, Choi JS 2011. Protein tyrosine phosphatase $1 \mathrm{~B}$ and $\alpha$-glucosidase inhibitory phlorotannins from edible brown algae, Ecklonia stolonifera and Eisenia bicycles. Biosci Biotech Bioch 75: 1472-1480.

Naganuma M, Nishida M, Kuramochi K, Sugawara F, Yoshida H, Mizushina Y 2008. 1-Deoxyrubralactone, a novel specific inhibitor of families $\mathrm{X}$ and $\mathrm{Y}$ of eukaryotic DNA polymerases from a fungal strain derived from sea algae. Bioorg Med Chem 16: 2939-2944.

Nagle DG, Zhou Y 2009. Marine natural products as inhibitors of hypoxic signaling in tumors. Phytochem Rev 8: 415-429.

Osterhage C, Kaminsky R, König GM, Wright AD 2000. Ascosalipyrrolidinone A, an antimicrobial alkaloid, from the obligate marine fungus Ascochyta salicorniae. J Org Chem 65: 6412-6417.

Osterhage C, König GM, Höller U, Wright AD 2002a. Rare sesquiterpenes from the algicolous fungus Drechslera dematioidea. J Nat Prod 65: 306-313.

Osterhage C, König GM, Jones PG, Wright AD 2002b. 5-Hydroxyramulosin, a new natural product produced by Phoma tropica, a marine-derived fungus isolated from the alga Fucus spiralis. Planta Med 68: 10521054 .

Ovenden SPB, Nielson JL, Liptrot CH, Willis RH, Wright AD, Motti CA, Tapiolas DM 2011. Comosusols A-D and comosone A: cytotoxic compounds from the brown alga Sporochnus comosus. J Nat Prod 74: 739-743.

Pang KL, Mitchell JI 2005. Molecular approaches for assessing fungal diversity in marine substrata. Bot Mar 48: 332-347.

Pei-Gen X, Shan-Lin F 1986. Traditional antiparasitic drugs in China. Parasitol Today 2: 353-355.

Pontius A, Mohamed I, Krick A, Kehraus S, König GM 2008a. Aromatic polyketides from marine algicolous fungi. J Nat Prod 71: 272-274.

Pontius A, Krick A, Mersy R, Kehraus S, Foegen SE, Müller M, Klimo K, Gerhäuser C, König GM 2008b. Monodictyochromes $\mathrm{A}$ and $\mathrm{B}$, dimeric xanthone derivatives from the marine algicolous fungus Monodictys putredinis. J Nat Prod 71: 1793-1799.

Pontius A, Krick A, Kehraus S, Foegen SE, Müller M, Klimo K, Gerhäuser C, König GM 2008c. Noduliprevenone: a novel heterodimeric chromanone with cancer chemopreventive potential. Chem Eur J 14: 98609863.

Qiao MF, Ji NY, Miao FP, Yin XL 2011. Steroids and an oxylipin from an algicolous isolate of Aspergillus flavus. Magn Reson Chem 49: 366-369.

Qiao MF, Ji NY, Liu XH, Li K, Zhu QM, Xue QZ 2010. Indoloditerpenes from an algicolous isolate of Aspergillus oryzae. Bioorg Med Chem Lett 20: 56775680.

Qiao Y-Y, Ji N-Y, Wen W, Yin X-L, Xue Q-Z 2009. A new epoxy-cadinane sesquiterpene from the marine brown alga Dictyopteris divaricata. Mar Drugs 7: 600-604.

Qin J, Su H, Zhang Y, Gao J, Zhu L, Wu X, Pan H, Li X 2010. Highly brominated metabolites from marine red alga Laurencia similis inhibit protein tyrosine phosphatase 1B. Bioorg Med Chem Lett 20: 7152-7154.

Simmons TL, Coates RC, Clark BR, Engene N, Gonzalez D, Esquenazi E, Dorrestein PC, Gerwick WH 2008. Biosynthetic origin of natural products isolated from marine microorganism-invertebrate assemblages. $P$ Natl Acad Sci USA 105: 4587-4594.

Strobel G, Daisy B, Castillo U, Harper J 2004. Natural products from endophytic microorganisms. J Nat Prod 67: 257-268.

Rui F, Boland W 2010. Algal pheromone biosynthesis: stereochemical analysis and mechanistic implications in gametes of Ectocarpus siliculosus. J Org Chem 75: 3958-3964. 
Sakai R, Minato S, Koike K, Koike K, Jimbo M, Kamiya H 2005. Cellular and subcellular localization of kainic acid in the marine red alga Digenea simplex. Cell Tissue Res 322: 491-502.

Smit AJ 2004. Medicinal and pharmaceutical uses of seaweed natural products: A review. J Appl Phycol 16: 245-262.

Sokolova EV, Barabanova AO, Homenko VA, Solov'eva TF, Bogdanovich RN, Yermak IM 2011. In vitro and ex vivo studies of antioxidant activity of carrageenans, sulfated polysaccharides from red algae. Bull Exp Biol Med 150: 426-428.

Sotokawa T, Noda T, Pi S, Hirama M 2000. A three-step synthesis of halomon. Angew Chem Int Edit 39: 34303432.

Tan RX, Zou WX 2001. Endophytes: a rich source of functional metabolites. Nat Prod Rep 18: 448-459.

Tarman K, Lindequist U, Wende K, Porzel A, Arnold N, Wessjohan LA 2011. Isolation of a new natural product and cytotoxic and antimicrobial activities of extracts from fungi of Indonesian marine habitats. Mar Drugs 9: 294-306.

Teixeira VL 2009. Produtos naturais marinhos. In: Pereira RC, Soares Gomes (org.). Biologia Marinha. Rio de Janeiro: Interciência, p. 443-471.

Thomas NV, Kim S-K 2011. Potential pharmacological applications of polyphenolic derivatives from marine brown algae. Environ. Toxicol Phar 32: 325-335.

Vairappan CS, Ishii T, Lee TK, Suzuki M, Zhaoqi Z 2010. Antibacterial activities of a new brominated diterpene from Borneon Laurencia spp. Mar Drugs 8: 17431749.

Vallim MA, Barbosa JE, Cavalcanti DN, De-Paula J-C, Silva VAGG, Teixeira VL, Paixão ICNP 2010. In vitro antiviral activity of diterpenes isolated from the Brazilian brown alga Canistrocarpus cervicornis. $J$ Med Plant Res 22: 2379-2382.

Viano Y, Bonhomme D, Ortalo-Magné A, Thomas OP, El Hattab M, Piovetti L, Blache Y, Culioli G 2011. Dictyotadimer A, a new dissymmetric bis-diterpene from a brown alga of the genus Dictyota. Tetrahedron Lett 52: 1031-1035.

Yang RY, Li CY, Lin YC, Peng GT, She ZG, Zhou SN 2006. Lactones from a brown alga endophytic fungus (No. ZZF36) from the South China Sea and their antimicrobial activities. Bioorg Med Chem Lett 16: 4205-4208.

Wang S, Li XL, Teuscher F, Li DL, Diesel A, Ebel R, Proksch
P, Wang BG 2006. Chaetopyranin, a benzaldehyde derivative, and other related metabolites from Chaetomium globosum, an endophytic fungus derived from the marine red alga Polysiphonia urceolata. $J$ Nat Prod 69: 1622-1625.

Wen W, Li F, Ji N-Y, Li X-M, Cui C-M, Li X-D, Zhang L-N, Xue Q-Z, Wang B-G 2009. A new cadinane sesquiterpene from the marine brown alga Dictyopteris divaricata. Molecules 14: 2273-2277.

Wijesekara I, Pangestuti R, Kim S 2011. Biological activities and potential health benefits of sulfated polysaccharides derived from marine algae. Carbohyd Polym 84: 14-21.

Wijesinghe WAJP, Jeon Y-J 2011. Biological activities and potential cosmeceutical applications of bioactive components from brown seaweeds: a review. Phytochem Rev 10: 431-443.

Wyk AWWV, Zuck KM, McKee TC 2011. Lithothamnin A, the first bastadin-like metabolite from the red alga Lithothamnion fragilissimum. J Nat Prod 74: 12751280.

Zhang Y, Li XM, Wang BG 2007a. Nigerasperones A C, new monomeric and dimeric naphto- $\gamma$-pyrones from a marine alga-derived endophytic fungus Aspergillus niger EN-13. J Antibiot 60: 204-210.

Zhang Y, Li XM, Wang CY, Wang BG 2007b. A new naphthoquinoneimine derivative from the marine algal-derived endophytic fungus Aspergillus niger EN-13. Chinese Chem Lett 18: 951-953.

Zhang Y, Li XM, Feng Y, Wang BG 2010. Phenethyl- $\alpha$-pyrone derivatives and cyclodipeptides from a marine algous endophytic fungus Aspergillus niger EN-13. Nat Prod Res 24: 1036-1043.

Zhu TJ, Du L, Hao PF, Lin ZJ, Gu QQ 2009. Citrinal A, a novel tricyclic derivative of citrinin, from an algicolous fungus Penicillium sp. i-1-1. Chinese Chem Lett 20: 917-920.

\section{*Correspondence}

Hosana Maria Debonsi

Departamento de Física e Química, Núcleo de Pesquisas de Produtos Naturais e Sintéticos, Faculdade de Ciências Farmacêuticas de Ribeirão Preto, Universidade de São Paulo Av. do Café, s/n, Monte Alegre, Ribeirão Preto, SP, Brazil hosana@fcfrp.usp.br

Tel.: +55163602 4713

Fax: +551636024243 